\title{
ABB REVIATIONS
}

$\begin{array}{ll}\text { BL } & \text { British Library } \\ \text { EETS } & \text { Early English Text Society } \\ \text { ES } & \text { Extra Series } \\ \text { MED } & \text { Middle English Dictionary } \\ \text { NA } & \text { National Archives, Kew } \\ \text { NS } & \text { New Series } \\ \text { OED } & \text { Oxford English Dictionary } \\ \text { OS } & \text { Original Series } \\ \text { SS } & \text { Supplementary Series }\end{array}$

xii 